\title{
Ciletuh Geopark: Toward the Tourism Industry
}

\author{
M.B. Santoso*, N.C. Apsari, S.T. Raharjo, \\ Universitas Padjadjaran \\ Bandung, Indonesia \\ *meilanny.budiarti@unpad.ac.id
}

\begin{abstract}
A Geopark consist of geological, biological and cultural varieties thus it is unavoidable becoming tourist attraction which opens the possibility for the local community to offer various kinds of ser-vices and goods needed to support the tourist in-dustry. This will improve the welfare of the local community. This study is aiming to look the pre-paredness of the local community in receiving the status of geopark in Ciletuh Palabuanratu Indo-nesia. Using descriptive method and qualitative approach, data were gained through interviewed stakeholders and local people involved in the de-velopment of the geopark. The result shows vari-ous stakeholders have worked together promoting and preparing Ciletuh to become geopark. How-ever, the community has not yet prepared to re-ceive the significant impact from the status of Ciletuh as geopark. An effort in improving the lo-cal community capacity becomes necessary be-cause tourism activity is closely related to the interaction between the local community and the tourists.
\end{abstract}

\section{Keywords-Geopark; Community; Tourism}

\section{INTRODUCTION}

In 2014-2015 UNWTO (The World Tourism Organization) and WTTC (World Travel \& Tourism Council) explain the strategic rationale data of tour-ism in the world, that in 2014, $9.5 \%$ of PDB of countries in the world comes from tourism sector both from the direct and indirect impacts. In 2014 around 1,138 million overseas tourists and 5-6 billion domestic tourists enjoyed tourism sector. The data place tourism as a featured sector in the level of the world.

Indonesia as an archipelago country has a geographical condition with beautiful and gorgeous nature. A large range of ocean surrounds thousands of islands lived by various ethnicities with their customs and cultures. Those heaps of God's gift make Indonesia appeal to become a tourist destination, not only for domestic tourists but also for overseas tourists.

Besides the various beauty of the tourist destinations, the geographical condition of Nusantara, like landscape, rocks, fossils, faults, and folds become a gift for this country. The geological elements in Indonesia are known as a geopark. An existence of a geopark does not only serve as a property of monumental nature geological, but also as a showcase of the life in exhibiting the existence of humans, animals, and plants. In other words, a geopark area has geological and biological varieties, as well as cultural varieties.

International Geoparks Network [1] UNESCO (2006) defined geopark as a region with outstanding geological aspects, covering one or more important scientific sites, not only due to geological reasons, but also based on archeology, ecology and cultural aspects. In this regard, geopark is not only perceiving as Earth Park connected with conservation and tourism aspects, but also integrating the geological heritages organization with cultural heritages of certain region for three main objectives, which are conservation, education and sustainable development [2]. Through geopark, the geological heritage is utilized to raise the awareness of the community on issues dealing with earth dynamic occurring around us [3].

In line with the meaning of geopark, a geopark area has its own attractiveness. It is unavoidable if a geopark area appeals tourists to visit and enjoy various beauty offered. The existence of Ciletuh National Geopark was inaugurated in 2015. It enriches and completes tourist destinations in West Java, especially in Sukabumi District. Like other tourist destinations in Indonesia, it is located in a remote area. Visi-tors have to go on a long journey to reach the geopark area. The development of various supporting facilities, like infrastructure and amenity core, be-comes a necessity for the local government and other parties who have special concern on the development of a geopark area. Moreover, the natural potentials and cultures become an attractiveness of a geopark area that significantly will appeal the tourists. A study by [4] regarding Langkawi Geopark shows that the development of a geopark can improve the social and economic capacity of the local community. Even further, [5] see that the development of a geopark does not only improve the prosperity of the local community but also protects the culture as well as the identity of the local community.

The increasing number of tourists visiting geopark area, opening business opportunity for the local community around the geopark by providing various needs for the tourists during their stay. This opportunity can be utilized by the community by offering services or goods, such as accommodation, tour guide, and amenity core. If the opportunity is well utilized by the community then it may improve the income level of the local community around the geopark area.

Based on the condition above, the local community needs to prepare themselves and optimize the human resources to be able to take a part in developing the geopark area along with the local development which leads to an improvement of local community prosperity in the geopark area.

\section{METHOD}

This study was conducted using the descriptive method and qualitative approach. The data were gained from primary and 
secondary data [6]. The data collection techniques were observation, interview, literature study, and document study. The data validity was done by data triangulation, by checking data gained through some other data sources. The informants in this study were the local community, Paguyuban Alam Pakidulan Sukabumi (PAPSI) as the local association that has concern and focus on Ciletuh Geopark management activity and the local government.

\section{RESULTS AND DISCUSSION}

Ciletuh National Geopark inaugurated on 22nd December 2015 is located in two different sub-districts, namely Ciemas Sub-district and Ciracap Sub-district covering fifteen villages. Ciemas Sub-district covers nine villages, namely Tamanjaya, Ci-waru, Girimukti, Mekarsakti, Ciemas, Mandrajaya, Cibenda, Sidamulyo, and Mekarjaya. Meanwhile, Ciracap Subdistrict has six villages: Gunungbatu, Cikangkung, Mekarsari, Ujungggenteng, Pangumba-han, and Purwasedar. The coverage of both sub-districts is $45,820 \mathrm{Ha}$.

Located in 45,820 Ha area, Ciletuh National Geopark is divided into a couple of areas: (1) conservation area covering Cikepuh wildlife reserve, Cibanteng natural preserve, Penyu Pangumbahan and Cultural Sites; (2) cultivation area covering fishpond, plantation, agriculture, housing and production forest; (3) special area for KOSTRAD training area; and (4) developing area covering tourism area, sea, waterfall, agrotourism and cultural tourism. Those are-as become wealth, feature and even pre-requirement of an area to be a geopark area which cover 45,820 Ha, 15 villages, 2 sub-districts

In line with an effort to encourage the growth and development of Ciletuh National Geopark, the government of West Java commits and fights for an area extension of Ciletuh National Geopark which at first only covered two sub-districts consisting of fifteen villages. On 21st June 2016, it was officially announced that the coverage became eight subdistricts consisting of seventy-four villages. The change of name from the provincial government into CiletuhPalabuhanratu National Geopark was inau-gurated with its 126,100 ha breadth; it equals to $1,261 \mathrm{~km} 2$. The effort to extend the geopark is to be able to get into the world geopark network or UNESCO Global Geopark (UGG) announced by UNESCO on 22nd December 2017 [7].

The borders of Ciletuh-Palabuhanratu National Geopark, consist of eight sub-districts and by geo-area is divided into three geo-areas, namely Cisolok Geoarea which development carries a theme of an-cient magmatic zone shifting, forearc evolution, Jampang Geo-area whose development carries a theme of Jampang plateau landscape, and Ciletuh Geo-area with a theme of subduction zone uplifted rocks. Certainly, those geo-areas offer their own attractiveness and features for tourists. In the middle of various beauty and natural potentials offered by the geopark area or other tourist destinations in remote areas, infrastructure and other amenity cores become an important thing that needs to be prepared and provided.

The extension of Ciletuh National Geopark into CiletuhPalabuhanratu National Geopark is seen in Picture 2 below.
To Travel to Ciletuh-Palabuhanratu National Geopark from the big city, for instance from Jakarta or Bandung, visitors have to go through $\pm 200 \mathrm{Km}$ of distance. If it is not supported by a proper infrastructure, it will take a long time to reach. Moreover, the government of West Java Province has promoted the geopark as a leading tourist destination in West Java.

In relation to the existence of Ciletuh-Palabuhanratu National Geopark in a remote area, the most important thing to do is working together with stakeholders involved in the process of development of the geopark area, as what the gained data elaborate.

Infrastructure aspect is a major aspect that needs to be prepared properly to ease and comfort visitors coming to Ciletuh-Palabuhanratu National Geopark. Parties taking a role in fixing the road infrastructure to Ciletuh-Palabuhanratu National Geopark area are the government and Biofarma Company. In this case, the government fixes the road infrastructure to Ciletuh-Palabuhanratu National Geopark area and builds information panels and directions to the ge-opark area. In relation to the road construction, in 2017 the provincial government has planned to build a new road from Palabuhanratu to Darma Peak as one of the tourist destinations in Ciletuh-Palabuhanratu National Geopark area. On the other hand, Biofarma Company takes a role to provide infrastructures, such as information panels, directions, clean water sanitation, toilets, bins, and Geopark In-formation Center (GIC). Those infrastructures are in line with the prerequirements set by UNESCO in the process of CiletuhPalabuhanratu National Geopark assessment to get listed on the world geopark network or UNESCO Global Geopark (UGG).

Facility provision is to support the local community around Ciletuh to be ready in facing the existence of CiletuhPalabuhanratu National Geopark. Practically, there are three parties working together in the facility provision for the local community around Ciletuh. They are the government, Biofarma Company and Paguyuban Alam Pakidulan Sukabumi (PAPSI). The roles are: (1) in relation to homestay, bed provision becomes the need for homestay owners. In the process of the provision, PAPSI takes a role in proposing the beds to the local government, (2) in the program of improving youth capacity joined in GUAY Community, screen printing equipment is needed to produce gifts for tourists. In this case, PAPSI takes a role in proposing the screen-printing equipment to Biofarma Company, (3) the provision of clean water is done by Biofarma Company with one unit of $\pm 700 \mathrm{~m}$ length of pipe and the construction of drilled well for the local community, (4) improving health services in the center of community health by building an emergency center by Biofarma Company, and (5) for improving the business sector for PKK around the geopark area, PAPSI provides a crackers machine maker.

At this stage, the information announcement for the community and visitors regarding the existence of geopark in Ciletuh is done by the government, Biofarma Company and PAPSI. The roles for each party are: (1) the government conveys the information, (2) Biofarma Company announces infor-mation by making information boards of geopark tourist destination, and (3) PAPSI gives information about the tourist 
destination, a guide for visitors as well as information related to accommodation and transportation at Ciletuh geopark area.

It is only the government and Biofarma Company that take a role in funding aspect. PAPSI, in this case, takes a role as the party who proposes funding to both institutions. There are two different patterns in the funding aspect: (1) Biofarma Company hands the fund to the community based on proposals pro-posed by PAPSI, while (2) the funding from the government is allocated to the community based on the government decision through an official notifica-tion, budget and the condition of activities that have been planned beforehand by the government based on the local community proposals from the discussion of development planning (musrenbang: musyawarah rencana pembangunan) in their area.

Besides building infrastructures in Ciletuh Ge-opark area, the government of West Java Province also signs a mutual agreement of the geopark area development with a number of parties like the local government of Sukabumi District, PTPN VIII, Biofarma Company, Jawi Regional Housing (PD), BJB Bank, Universitas Padjadjaran, and tourism driving forum.

Certainly, the lots of processes of the geopark area development do not escape from the process of developing the area where the geopark area is situated. In this case, it is the villages that spread through Ciletuh-Palabuhanratu National Geopark area. Since the beginning of the development of the geopark area, the road access has been built and the number of tourist has increased significantly. As a result of that, the community who were more enclosed, nowadays are exposed to different cultures. This influences their social psychology aspect as well as the relation-ship of the community in the geopark area.

A destination is considered providing tourism development if beforehand, there have been tourism activities. To be able to increase the potentials, it is important to plan a much better development. According to [8], three main principles in sustainability development are:

\section{A. Ecological sustainability}

It is to ensure that the development done is in line with the process of ecology, biology and the existing ecological resources.

\section{B. Social and Cultural Sustainability}

It ensures that the development gives a positive impact on the community around the geopark and it is in line with customs and values applied in the community.

\section{Economic Sustainability}

It ensures that the development is economically efficient and the resources used can linger for the need in the future.

The development of a geopark area is in accordance to ecotourism that actively contributes to activities of natural and cultural conservation and involves the local community in planning, developing and managing the tourism as well as giving a positive contribution to the community prosperity. The development itself is done in the form of independent tourism or organized in a small group [9] [10]). In other words, ecotourism is a form of tourism industry based on the environment that gives a small impact on natural and local culture damage. At the same time, it creates job opportunity and in-come as well as helps the conservational nature itself [11]. Therefore, an effort to in-crease the capacity and the community income is a must because tourism activities attach with the inter-action of the surrounding community with the tourists. [12] see that the development of community-based and continuous tourism can be done through developing tourism villages. Through developing them, it is expected that equity can be achieved in line with the concept of lingering tourism development. The presence and management of tourism village make the product of tourism exhibit the identity of rural cultures.

Based on the study conducted, there are some important works to be done by the government and related parties in developing the geopark area and other surrounding local development described as follows.

It is urgent that infrastructure capacity be improved to ease the tourists to go to the tourist destination as well as to develop the potentials of tourist destination needed by the tourists; The central government should concern about this leading tourist destination as soon as possible because the facility of tourist activities and the environment in this area are still laking so that the tourists still feel less comfortable and safe; The government should work together with private parties and the community, especially regarding funding and the management of tourism environment; Annual events through printed and electronic media promotions should be done continuously; The ability of human resources around the area to create creative works as an attraction for tourists should be improved so they will spend their money for the works. In anticipating unpredictable disasters, an effort to give counseling and training to the local community when the disaster happens can be done. It is also done to improve the quality of disaster mitigation-based facility so that the tourists keep safe.

The role of the local community in constructing and developing Ciletuh Geopark, South Sukabumi becomes an important part. The genuine participation of the local community by involving the entire com-munity in overall stages of development, starting from the planning process, decision making and su-pervision of the developing tourism village program [12] [13]. Having an active participation of the local community in each stage of activity, it is expected they could get knowledge, awareness, and independence of the local community. Moreover, the impact of the local community prosperity can be realized sustainably.

\section{CONCLUSION}

The development of the geopark area has to be seen and considered as one intact unity. The indica-tor of the local community prosperity at Ciletuh Geopark is not only measured based on economic in-come only. Geological, biological and cultural diver-sity in the unity of Ciletuh Geopark is a potential (miracle) that need to be maintained and protected by stakeholders. The local community as the most important stakeholder [14] must gain the first and main benefits from the development of Ciletuh Geopark. An improvement of partic- 
Langkawi Geopark, Malaysia. Shima: The International Journal of Research into Island Cultures, 5(1).

ipation of the community is also one of the efforts in improving the local community prosperity.

In the process of constructing Ciletuh-Palabuhanratu Geopark area, the government of Sukabumi District and the provincial government of West Java must help each other and keep synergizing to be able to complete all pre-requirements to be listed in the network of UNESCO Global Geopark (UGG) as well as possible. By working together with various parties, such as Universitas Padjadjaran as the higher education party, Biofarma Company as the business party, PTPN VIII as the BUMN party, PD Jawi as the local company party, BJB Bank as the banking party and the tourism driving forum, it is expected that all processes of development at CiletuhPalabuhanratu Geopark area will accelerate and run smoothly. The Penta helix partnership in the development of Ciletuh Geopark, South Sukabumi area has to be comprehended and built with full of awareness and respect of mutual partners.

\section{REFERENCES}

[1] Azman, N. Halim, S.A. Liu, O.P. Saidin, S. \& Komoo, I. (2010). Public education in heritage conservation for geopark community. ProcediaSocial and Behavioral Sciences, 7: 504-511.

[2] Masrul, K.F. \& Suroso, D.S.A. 2014. Studi Proses Pengajuan Kawasan Geopark Parahyangan Di Jawa Barat Sebagai Anggota Global Geopark Network UNESCO. Jurnal Perencanan Wilayah dan Kota SAPPK, 3(1): 77-86.

[3] Halim, S.A. Komoo, I. Salleh, H., \& Omar, M. 2011. The Geopark as a Potential Tool Alleviating Community Marginality: A case study of
[4] Farsani, N.T. Coelho, C. \& Costa, C. 2012. Geotourism and Geoparks as Gateways to Socio-cultural Sustainability in Qeshm Rural Areas, Iran. Asia Pacific Journal of Tourism Research, 17(1): 30 - 48.

[5] UNESCO Global Geopark Network. 2006. Published by division of ecological and earth sciences. UNESCO Paris.

[6] Black, J. 1999. Metoda dan Masalah Penelitian Sosial. Bandung: PT. Refika Aditama.

[7] Rosana, M. F. 2017. Geopark Ciletuh-Palabuhanratu Menuju UNESCO Global Geopark Bagaimana Unpad Berkontribusi (presentation material), Pusat Penelitan Geopark \& Kebencanaan Geologi, Universitas Padjadjaran

[8] McIntyre, George. 1993. Sustainable Tourism Development, Guide for Local Planners. World Tourism Organization

[9] UNEP. 2000. Impact of Tourism. UNEP Tourism

[10] Heher, S. 2003. Ecotourism Investment and Development Models: Donors, NGOs and Private Entrepreneurs. Cornell University.

[11] Ward, J. 2000. An Introduction to Travel and Tourism. Pearson Education.

[12] Fandeli, D. \&. Baiquni. 2013. Pengembangan Desa Wisata Berbasis Partisipasi Masyarakat Lokal di desa Wisata Jatiluwih Tabanan Bali. Jurnal Kawistara, 3(2): 129-139 Bersama Masyarakat dan Komunitas. Unpad Press.

[14] Raharjo, S.T. Darwis, R.S. Hidayat, E.N. Apsari, N.C. Humaedi, S. Santoso, M.B. Riana, A.W. 2017. Identifikasi Stakeholder Pengelolaan Geopark Ciletuh Sukabumi Jawa Barat. Pusat Studi Kewirausahaan Sosial, CSR dan Pengembangan Masyarakat FISIP - Unpad. Unpublished.
[13] Raharjo, S.T. 2015. Pekerjaan Sosial Generalis: Suatu Pengantar Bekerja 